\title{
PENYULUHAN DAN PELATIHAN BANTUAN HIDUP DASAR BAGI GURU SEKOLAH DASAR
}

\author{
Muhammad Jalaluddin Assuyuthi Chalil ${ }^{1}$ \\ Ika Nopa ${ }^{2}$ \\ ${ }^{1}$ Bagian Anestesi dan Reanimasi Fakultas Kedokteran UMSU \\ ${ }^{2}$ Bagian Ilmu Kesehatan Masyarakat Fakultas Kedokteran UMSU \\ ikanopa@umsu.ac.id
}

\begin{abstract}
ABSTRAK
Latar Belakang : Anak usia sekolah dasar terlibat dalam perilaku sosial dan motorik yang kompleks sehingga sangat aktif dalam berbagai aktivitas baik di dalam maupun luar kelas. Hal ini dapat menyebabkan keadaan gawat darurat yang membutuhkan pertolongan berupa bantuan hidup dasar. Kejadian gawat darurat yang tidak mendapat pertolongan segera dapat menyebabkan kecacatan bahkan kematian. Untuk itu diperlukan adanya pengetahuan dan ketermpilan bantuan hidup dasar yang baik oleh guru guru di sekolah dasar. Tujuan dilakukannya Penyuluhan dan Pelatihan Bantuan Hidup Dasar Bagi Guru Sekolah Dasar adalah meningkatnya pengetahuan dan ketermpilan bantuan hidup dasar yang baik oleh guru guru di sekolah dasar. Metode : Kegiatan pengabdian kepada masyarakat di laksanakan di SDN 060929, 060930, dan 064988, Kelurahan Pangkalan Masyhur, Kecamatan Medan Johor, Kota Medan. Media yang digunakan adalah: Power point presentasi, ,manekin bayi, manekin anak, dan manekin kompresi dada. Hasil : Kegiatan pengabdian kepada masyarakat berupa penyuluhan dan pelatihan bantuan hidup dasar pada guru di SDN 060929, 060930, dan 064988, Kelurahan Pangkalan Masyhur, Kecamatan Medan Johor, Kota Medan di hadiri oleh 44 orang guru. Pelaksanaan kegiatan berupa penyuluhan dengan presentasi powerpoit, peragaan/demonstrasi, dan simulasi kasus terkait bantuan hidup dasar.

Kata Kunci: Penyuluhan, Bantuan Hidup Dasar, Guru
\end{abstract}

\section{ABSTRACT}

Background: Primary school-age children are involved in complex social and motor behavior so that they are active in various activities both inside and outside the classroom. This fact can cause emergency situations that require basic life support. Emergency events that do not get immediate help can cause disability and even death. For this reason, it is necessary to have good basic life support knowledge and skills by teachers in elementary schools. The purpose of conducting Basic Life Assistance Education and Training for Elementary School Teachers is to increase knowledge and good basic life assistance skills by teachers in primary schools. Methods: Community service activities were carried out at SDN 060929, 060930, and 064988, Medan City. The media used are: PowerPoint presentation, baby mannequins, child mannequins, and chest compression mannequins. Results: Community service activities in the form of counseling and basic life support training for teachers at SDN 060929, 060930, and 064988, Medan City were attended by 44 teachers. Implementation of activities in the form of counseling with powerpoit presentations, demonstrations, and simulation

Keywords: Counseling, Basic Life Support, Teacher. 


\section{PENDAHULUAN}

Kejadian gawat darurat adalah kondisi korban mengalami henti nafas dana atau henti jantung. ${ }^{1}$ Kejadian gawat darurat yang membutuhkan pertolongan segara dapat terjadi kapan saja, dimana saja, dan menimpa siapa saja. Kejadian gawat darurat yang tidak mendapat pertolongan segera dapat menyebabkan kecacatan bahkan kematian. $^{2}$

Dalam keadaan gawat darurat dapat terjadi kematian, resiko kematian dapat diturunkan dengan pemberian Bantuan Hidup Dasar (BHD) pre hospital yang tepat pada pasien. Bantuan Hidup Dasar (BHD) adalah pertolongan medis yang diberikan kepada pasien yang mengalami gangguan pernapasan, henti jantung atau obstruksi jalan napas. ${ }^{3}$

Bantuan hidup dasar merupakan tindakan yang dilakukan dengan tujuan untuk membebaskan jalan napas, mambantu pernapasan dan mempertahankan sirkulasi darah tanpa menggunakan alat. ${ }^{4}$

Pengetahuan dan keterampilan yang diperlukan dalam melakukan bantuan hidup dasar pada anak adalah menilai sirkulasi darah dengan melakukan cek nadi, menilai dan memberikan bantuan pernafasan, melakukan kompresi dada, dan membebaskan jalan nafas. ${ }^{5}$ Dari hasil penelitian mengenai tingkat pengetahuan masyarakat tentang teori teknik kompresi di kota Jakarta selatan didapati hanya $42 \%$ dalam kategori baik. $^{6}$

Sekolah dasar (SD) adalah tempat menimba ilmu bagi anak usia berusia 6-12 tahun. Pada usia sekolah anak terlibat dalam perilaku sosial dan motorik yang kompleks. ${ }^{7}$ Sehingga anak sangat aktif dalam berbagai aktivitas baik di dalam maupun luar kelas. Keaktifan anak dapat menyebabkan kecelakaan yang membutuhkan penanganan secara cepat dan benar. Dari hasil penelitian terkait bantuan hidup dasar pada Guru SD sebelumnya didapati dari responden yang diteliti hanya $32 \%$ guru yang pernah mendapat pelatihan bantuan hidup dasar. ${ }^{8}$

Penyuluhan dan pelatihan bantuan hidup dasar merupakan upaya yang penting dilakukan untuk meningkatkan pengetahuan dan 
keterampilan masyarakat awam dalam memberikan pertolongan pre hospital.

Berdasarkan latar belakang diatas penulis tertarik untuk melakukan pengabdian kepada masyarakat berupa penyuluhan dan pelatihan bantuan hidup dasar pada guru di SDN 060929, 060930, dan 064988, Kelurahan Pangkalan Masyhur, Kecamatan Medan Johor, Kota Medan.

\section{METODE}

Kegiatan pengabdian kepada masyarakat di laksanakan di SDN 060929, 060930, dan 064988, Kelurahan Pangkalan Masyhur, Kecamatan Medan Johor, Kota Medan pada tanggal 27 Juli 2019. Media yang digunakan adalah:

1. Power point presentasi penyuluhan

2. Manekin bayi, Manekin anak, dan Manekin kompresi dada yang digunakan untuk peragaan cara melakukan bantuan hidup dasar berupa Resusitasi Jantung Paru, Back Blow, Hemlich
Manuver, dan Chest Thrust serta simulasi kasus

\section{HASIL}

Kegiatan pengabdian kepada masyarakat berupa penyuluhan dan pelatihan bantuan hidup dasar pada guru di SDN 060929, 060930, dan 064988, Kelurahan Pangkalan Masyhur, Kecamatan Medan Johor, Kota Medan berjalan dengan lancar. Peserta kegiatan berjumlah 44 orang guru yang terdiri dari 11 orang laki laki dan 33 orang perempuan.

Terdapat beberapa tahapan dalam pelaksanaan pengabdian kepada masyarakat ini yakni :

1. Tahap persiapan yang terdiri dari:

a. Survei tempat pelaksanaan kegiatan.

b. Melaksanakan observasi dan wawan cara ke mitra untuk menentukan prioritas.

c. Melakukan proses pengumpulan data guna mempersiapkan bahan dalam proses perancangan

d. Pembuatan proposal

e. Persiapan tempat dan alat untuk pelaksanaan kegiatan 
2. Tahap Pelaksanaan penyuluhan dan pelatihan bantuan hidup dasar pada guru kegiatan yang terdiri dari

a. Perkenalan

b. Pemaparan Materi

c. Sesi Tanya Jawab

d. Peragaan cara melakukan Resusitasi Jantung Paru, Back Blow, Hemlich Manuver, dan Chest Thrust

e. Simulasi

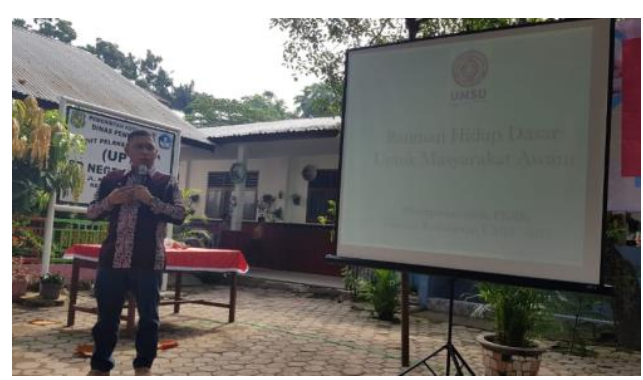

Gambar 1. Pemaparan Materi Bantuan Hidup Dasar

Dalam tahap pemaparan materi dilakukan presentasi mengenai defenisi bantuan hidup dasar, tujuan melakukan bantuan hidup dasar, pentingnya memiliki kemampuan bantuan hidup dasar bagi para guru, dan tahapan dalam bantuan hidup dasar.

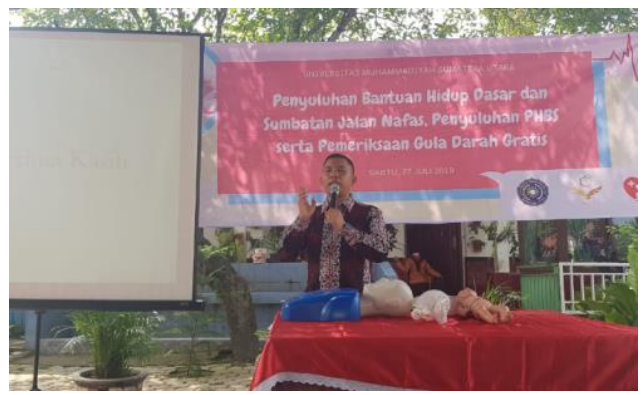

Gambar 2. Sesi Tanya Jawab

Dalam Sesi Tanya Jawab dberi kesempatan bagi responden untuk bertanya terkait materi yang telah dipaparkan sebelumnya

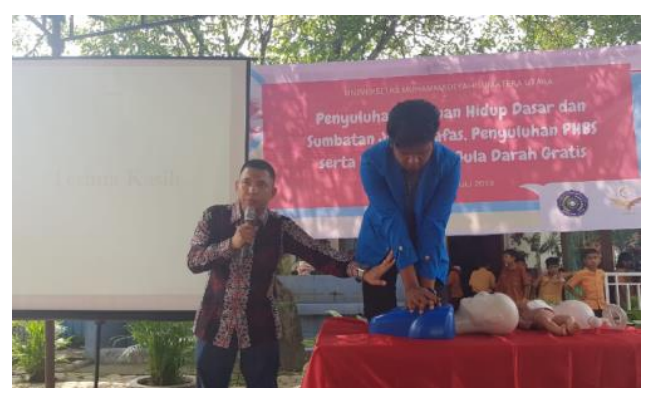

Gambar 3. Peragaan cara melakukan resusitasi jantung paru

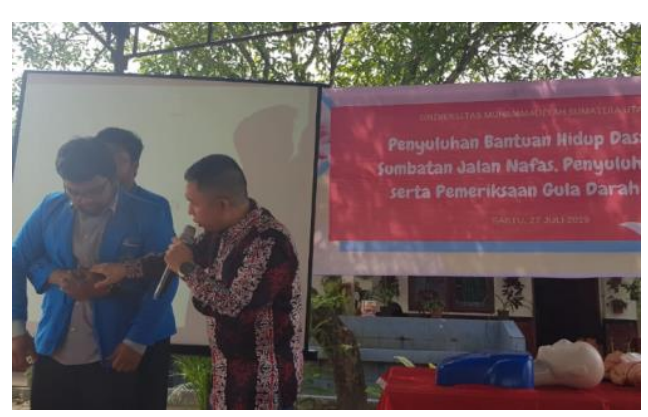

Gambar 4. Peragaan cara melakukan Hemlich Manuver 


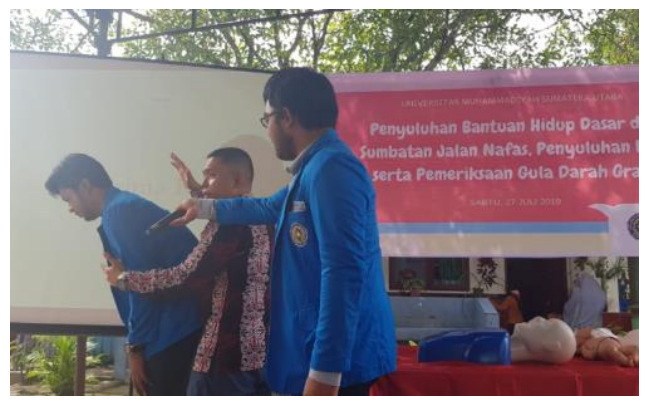

Gambar 5. Peragaan cara melakukan back blow

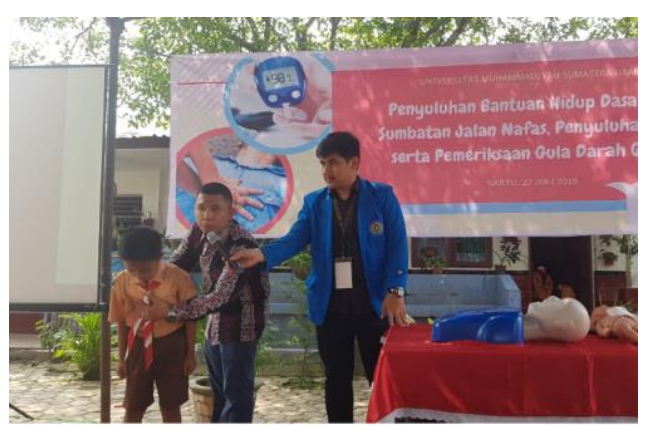

Gambar 6. Simulasi Kasus

3. Tahap akhir yakni setelah pelaksanaan kegiatan penyuluhan dan pelatihan bantuan hidup dasar pada guru di SDN 060929, 060930, dan 064988, Kelurahan Pangkalan Masyhur, Kecamatan Medan Johor, Kota Medan maka dilanjutkan dengan analisis dan evaluasi hasil kegiatan serta publikasi hasil kegiatan.

\section{DISKUSI}

Pengabdian kepada masyarakat berupa penyuluhan dan pelatihan bantuan hidup dasar pada guru dilakukan di SDN 060929, 060930, dan 064988 yang merupakan Sekolah Dasar Negri yang terletak di wilayah binaan FK UMSU yakni Kelurahan Pangkalan Masyhur. Kegiatan pengabdian kepada masyarakat ini dilakukan untuk meningkatkan pengetahuan dan kemampuan para guru dalam melakukan bantuan hidup dasar dimana siswa sekolah dasar

\section{KESIMPULAN}

Kegiatan pengabdian kepada masyarakat berupa penyuluhan dan pelatihan bantuan hidup dasar bagi guru SD di kelurahan pangkalan masyhur. Kegiatan berupa presentasi, peragaan, dan simulasi kasus bantuan hidup dasar dihadiri oleh 44 orang guru yang berlangsung aktif dan antusias. Kegiatan ini bermanfaat untuk meningkatkan pengetahuan guru SD dalam melakukan bantuan hidup dasar. Saat Sekolah Dasar anak terlibat dalam perilaku sosial dan motorik yang kompleks sehingga sangat aktif dalam berbagai aktivitas baik di dalam maupun luar kelas. Hal ini dapat menyebabkan keadaan 
gawat darurat yang membutuhkan pertolongan berupa bantuan hidup dasar. $^{7}$

Dari hasil penelitian sebelumnya didapati adanya hubungan penyuluhan dan pelatihan bantuan hidup dasar terhadap pengetahuan tentang bantuan hidup dasar pada guru SD. ${ }^{8}$

Dari hasil kegiatan berupa demonstrasi dan simulasi bantuan hidup dasar yang dilakukan bagi warga di perumahan di kota Semarang didapati adanya peningkatan pengetahuan dan keterampilan warga dalam melakukan bantuan hidup dasar berupa. ${ }^{9}$

Dari hasil kegiatan berupa penyuluhan bantuan hidup dasar yang dilakukan bagi siswa SMA Negri 5 Denpasar didapati peningkatan pengetahuan siswa. ${ }^{10}$

\section{UCAPAN TERIMAKASIH}

1. Kepada Fakultas Kedokteran Universitas Muhammadiyah Sumatera Utara yang telah menyediakan media untuk pelaksanaan kegiatan pengabdian jepada masyarakat ini

2. Kepada mahasiswa angkatan 2016 Fakultas Kedokteran Universitas Muhammadiyah Sumatera Utara sebagai penyelenggara kegiatan pengabdian kepada masyarakat pada guru dan murid SD di wilayah binaan FK UMSU. Dimana kegiatan ini merupakan salah satu rangkaian kegiatan tersebut.

\section{DAFTAR PUSTAKA}

1. Thygeson, Alton, Gulli, Benjamin, Krohmer dkk. First Aid : Pertolongan Pertama edisi 5. Airlangga. Jakarta. 2011

2. Kementrian Kesehatan RI. Cara Atasi Kegawatdaruratan Secara Terpadu. Kementrian Kesehatan RI. 2016

3. American National Redcross. Basic Life Support for Provider Handbook. Stay Well Publisher : United States. 2015

4. Handley. A.J. Basic Life Support. British Jpournal of 
Anaesthesia. 1997; 79: 151158

5. American Health Association. Pediatric Basic Life Support. American Health Association Journal. 2018

6. Erawati, S. Tingkat Pengetahuan Masyarakat Tentang Bantuan Hidup Dasar di Kota Jakarta Selatan. Universitas Islam Negri Syarif Hidayatullah Jakarta. 2015

7. Burhaein E, Aktivitas Fisik Olah Raga Untuk Pertumbuhan dan Perkembangan Siswa SD. Indonesian Journal of Primary Education.Vol 1 No 1. 2017

8. Evelyn S. Winarti. W. Determinan Pengetahuan Bantuan Hidup Dasar dan Pertolongan Pertama Pada Guru Sekolah Dasar. Indonesian Journal of Health Development Vol 1 No 2. 2019

9. Arifianto, Nur Aini D, Kustriyan M. PKM
Sosialisasi dan Simulasi Bantuan Hidup Dasar Bagi Fungsionaris Warga RW VII Perumahan Graha Mandiri Kelurahan Patemon Kecamatan Gunung Pati Kota Semarang. Jurnal Implementasi Pengabdian Masyarakat Kesehatan. Vol 1 No 2. 2019

10. Agusini Buntari N, Suyasa DP, Treesna N, dkk. Penyuluhan dan Pelatihan Bantuan Hidup Dasar. Jurnal Paradharma Vol 1 No 2. 2017 